\title{
CONSUMERS BEHAVIOR ON ORGANIC FOOD: EVIDENCE FROM THE REPUBLIC OF SERBIA
}

\author{
Semir Vehapi ${ }^{1}$ Edin Dolićanin ${ }^{2}$
}

\begin{abstract}
Summary
In developed countries, the demand for organic food has seen a significant increase in the past decade. However, the organic food market in Serbia is still in its infancy and can be considered an emerging market. By gaining an understanding of consumer behavior on the Serbian market, it is possible to provide a greater consumption of organic food per capita through an appropriate marketing approach, as well as quicker development of the national market. This paper will outline some of the most significant findings obtained from a quantitative study of the population of Serbia in the role of buyers and potential buyers of organic food. How much knowledge respondents have about organic food was also studied and presented here, as was the socio-demographic profile of the consumers as an important determinant of organic food consumption. In addition, we also analyzed consumer behavior when buying organic food from the standpoint of basic instruments of the marketing mix: the product, the price, marketing communication (promotion) and marketing channels (place). The obtained results were explained in relation to the theoretical knowledge obtained from previous studies carried out on various national markets. Based on these findings, a solid foundation for the development of effective marketing strategies was obtained.
\end{abstract}

Key words: organic food, the market, consumers, behavior, Serbia

JEL: $M 30, Q 13, D 12$

\section{Introduction}

During the previous decade, the global organic food market developed very quickly from a niche market to a broad market segment (Doorn, Verhoef, 2015). The demand for organic food is growing at an increased rate, which has led to global sales of organic food and drink reaching 80 billion US dollars in 2014. In the same year, the per-capita consumption

1 Semir Vehapi, Ph.D., Assistant, State University of Novi Pazar, Department of Economic Sciences (office no. 23), Vuka Karadzica Street nn, 36300 Novi Pazar, Republic of Serbia, Phone: +381638618 381, E-mail: svehapi@np.ac.rs

2 Edin Dolićanin, Ph.D., Assistant Professor, State University of Novi Pazar, Department of Technical Sciences, Vuka Karadzica Street nn, 36300 Novi Pazar, Republic of Serbia, Phone: +381 636655 02, E-mail: edin.dolicanin@yahoo.com

EP 2016 (63) 3 (871-889) 
of these products was 11 US dollars, where the highest consumption rate was realized in Switzerland (221 €), Luxemburg (164€), and Denmark (162 €). However, even in these pioneer countries, organic food only makes up a small market share (Denmark: 7.6\%; Switzerland: 7.1\% and Luxemburg: 3.4\%) (Willer, Lernoud, 2014).

The organic food market in Serbia is still in its infancy, but the number of producers in the last decade has increased significantly. In 2014, there were 1,281 producers cultivating approximately 9,548 ha of organic agricultural land. The organic agricultural land makes up $0.2 \%$ of the overall agricultural land. This production capacity meets the current level of organic food consumption on the national market. The overall turnover of the organic food sector in Serbia has been estimated at 40 million US dollars. The average annual expenditures for organic food are 5 US dollars per capita. Based on the aforementioned indicators, it is evident that the Serbian organic food market is lagging behind the markets of more developed countries (Table 1), as well as the markets of neighboring countries which are members of the European Union (EU) (Table 2). The main reasons for this are low levels of consumption, insufficient access to information on the part of the consumers, an inconsistent offer, a lack of product variety, poorly developed distribution channels and a low average income. (Vlahović et al., 2011; Kalentić et al., 2014).

Table 1. A comparative overview of the indicators of organic food market development in Serbia and in select developed countries 2014.

\begin{tabular}{|c|c|c|c|c|c|}
\hline Country & Area (ha) & $\begin{array}{c}\text { Share of all } \\
\text { agr. land (\%) }\end{array}$ & $\begin{array}{c}\text { Producers } \\
\text { (no.) }\end{array}$ & $\begin{array}{c}\text { Retail sales } \\
\text { (million } € \text { ) }\end{array}$ & $€ /$ person \\
\hline Serbia & 9,548 & 0.2 & 1,281 & $\begin{array}{c}35(2012) \\
(40 \$)\end{array}$ & $\begin{array}{c}4.4(2012) \\
(5 \$)\end{array}$ \\
\hline Austria & 525,521 & 19.4 & 22,184 & 1,065 & 127 \\
\hline Denmark & 165,773 & 6.3 & 2,565 & 912 & 162 \\
\hline Germany & $1.047,633$ & 6.3 & 23,398 & 7,910 & 97 \\
\hline Italy & $1.387,913$ & 10.8 & 48,662 & 2,145 & 35 \\
\hline France & $1,118,845$ & 4.1 & 26,466 & 4,830 & 73 \\
\hline United Kingdom & 521,475 & 3 & 3,526 & 2,307 & 36 \\
\hline Sweden & 501,831 & 16.4 & 5,406 & 1,402 & 145 \\
\hline Netherlands & 49,159 & 2.5 & 1,706 & 965 & 57 \\
\hline
\end{tabular}

Source: Willer, Lernoud, 2014, 2016;

Table 2. A comparative overview of the indicators of organic food market development in Serbia and in neighboring countries 2014.

\begin{tabular}{|l|c|c|c|c|c|}
\hline Country & Area (ha) & $\begin{array}{c}\text { Share of all } \\
\text { agr. land } \\
\text { (\%) }\end{array}$ & $\begin{array}{c}\text { Producers } \\
\text { (no.) }\end{array}$ & $\begin{array}{c}\text { Retail sales } \\
\text { (million } € \text { ) }\end{array}$ & €/person \\
\hline Serbia & 9,548 & 0,2 & 1.281 & $\begin{array}{c}35(2012) \\
(40 \$)\end{array}$ & $\begin{array}{c}4.4(2012) \\
(5 \$)\end{array}$ \\
\hline Romania & 289,252 & 2.1 & 14,159 & 80 & 4 \\
\hline
\end{tabular}




\begin{tabular}{|l|c|c|c|c|c|}
\hline Country & Area (ha) & $\begin{array}{c}\text { Share of all } \\
\text { agr. land } \\
\mathbf{( \% )}\end{array}$ & $\begin{array}{c}\text { Producers } \\
\text { (no.) }\end{array}$ & $\begin{array}{c}\text { Retail sales } \\
\text { (million } \mathbf{~})\end{array}$ & €/person \\
\hline Croatia & 50,054 & 3.8 & 2,194 & 99 & 23 \\
\hline Hungary & 124,841 & 2.7 & 1,672 & 25 & 2 \\
\hline Bulgaria & 74,351 & 2.4 & 3,893 & 7 & 1 \\
\hline Montenegro & 3,289 & 0.6 & 167 & 0 & 0 \\
\hline Bosnia and Herzegovina & 353 & 0.02 & 24 & 2 & 0 \\
\hline Macedonia & 3,146 & 0.3 & 382 & - & - \\
\hline Albania & 515 & 0.04 & 39 & - & - \\
\hline
\end{tabular}

Source: Willer, Lernoud 2014, 2016;

Numerous studies have focused on individual instruments of the marketing mix in the context of organic food. A certain number of them have dealt with the different aspects of the production mix, including attractive packaging and its role in the purchasing process (Hill, Lynchehaun, 2002; Essoussi, Zahaf, 2008), knowledge of the labels of organic food and certification standards (Padel, Foster, 2005; Wier et al., 2008; Janssen, Hamm, 2011) and the product range (Govindasamy et al., 2006). These findings indicate that packaging is an important means to distinguish organic from conventional food, but that it is still not attractive enough for most organic products. In addition, there is a smaller variety of organic products in comparison to conventional ones. Furthermore, the obtained data also confirm that consumers are manifesting a certain amount of confusion or lack of knowledge in terms of the certification process and organic labels. When it comes to price as the second instrument of the marketing mix, most studies dealt with the consumers' willingness to pay for organic products (Radman, 2005; Tsakiridou et al., 2006; Krystallis et al., 2006; Pellegrini, Farinello, 2009; Aguirre González, 2009; Aryal et al., 2009). What is common to all these studies is the finding that consumers are willing to pay a higher price for organic food in comparison to the price of conventional food. Another very important question is where consumers purchase organic food. Accordingly, numerous studies have analyzed the behavior of consumers in terms of store choice behavior (Lockie et al., 2002; Fotopoulos, Krystallis, 2002; Padel, Foster, 2005; Wier et al., 2008; Crandall et al., 2010; MacKinnon, 2013). Even though the results differ, most of the studies agree that the importance of conventional retailers is increasing, and that supermarkets are becoming the main place where consumers purchase organic food (Graph 1.). A significantly smaller number of studies have analyzed the instruments of communication on the organic food market (Fotopoulos, Krystallis, 2002; Chinnici et al., 2002; Akbari, Asadi, 2008). On the market of Iran, Greece and Italy, consumers state that they mostly gather information on organic products by means of the electronic and printed media, but also from family members and friends. Another important aspects of research into the organic food market referred to the discovery of the consumer profile. Research has shown that organic food consumers are mostly women, the elderly, as well as married couples with children (Wandel, Bugge, 1997; Fotopoulos, Krystallis, 2002; Roitner-Schobesberger et al., 2008; Dimitri, Dettmann, 2012; Grubor, Djokić, 2016). It has also been determined that a higher education and higher income are related to the greater probability of purchasing 
organic products (Dimitri, Dettmann, 2012).

Graph 1. Marketing channels for organic products in selected countries 2014.

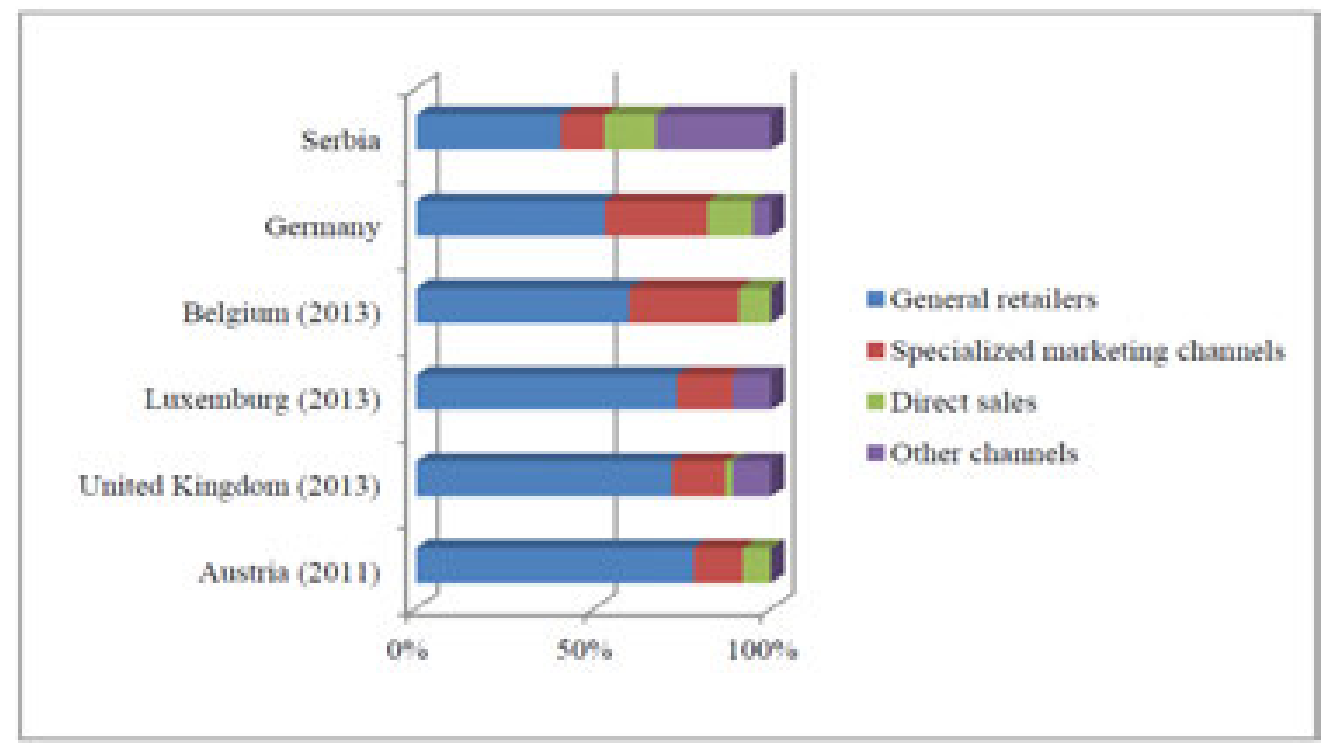

Source: Willer, Lernoud, 2016;

While previous studies have dealt with the different aspects of marketing research for organic food, this study encompasses four basic marketing instruments, focusing on organic food consumers, while at the same time discovering the socio-demographic profile of these consumers. In this way, the current study provides opportune way for researchers as well as practitioners to get a complete overview of the most important factors which determine organic food consumption on the Serbian market. Understanding the critical factors which influence consumer behavior towards organic food is of vital importance for the implementation of successful marketing strategies, and consequently the quick development of the national organic food market.

\section{Materials and methods}

\section{Sampling procedure and data collection technique}

The research presented in this paper is based on the findings obtained from a quantitative study by means of a questionnaire. The target population was made up of the population of the Republic of Serbia, who can find themselves in the role of buyers or potential buyers of organic food. Due to financial and logistic obstacles, this study could not focus on all the subjects of the target population. As a result, the study was carried out on a convenience sample which included 212 participants of different socio-demographic characteristics (Table 3.). The sample from each city was approximately the same in proportion to number of inhabitants. The participants were selected from five regional centers: Belgrade $=104$ respondents; Novi Sad $=31$ respondent; Niš $=28$ respondents; Kragujevac $=26$ respondents; 


\section{and Novi Pazar $=23$ respondents.}

Table 3. The socio-demographic characteristics of the respondents

\begin{tabular}{|c|c|c|c|}
\hline \multicolumn{2}{|c|}{ Element } & Absolute frequency & Relative frequency (\%) \\
\hline \multicolumn{2}{|l|}{ Gender } & & \\
\hline \multicolumn{2}{|l|}{ Male } & 85 & 40.1 \\
\hline \multicolumn{2}{|l|}{ Female } & 127 & 59.9 \\
\hline \multicolumn{2}{|l|}{ Age group } & & \\
\hline \multicolumn{2}{|l|}{$15-25$} & 92 & 43.4 \\
\hline \multicolumn{2}{|l|}{$26-35$} & 46 & 21.7 \\
\hline \multicolumn{2}{|l|}{$36-50$} & 52 & 24.5 \\
\hline \multicolumn{2}{|l|}{$51-65$} & 12 & 5.7 \\
\hline \multicolumn{2}{|l|}{ Over 65} & 10 & 4.7 \\
\hline \multicolumn{4}{|l|}{ Education } \\
\hline \multicolumn{2}{|l|}{ University } & 111 & 52.4 \\
\hline \multicolumn{2}{|l|}{ Community college } & 17 & 8.0 \\
\hline \multicolumn{2}{|l|}{ High school } & 78 & 36.8 \\
\hline \multicolumn{2}{|l|}{ Elementary } & 6 & 2.8 \\
\hline \multicolumn{4}{|l|}{ Work status and job } \\
\hline \multirow{5}{*}{$\begin{array}{l}\text { Full-time employee/ } \\
\text { Part-time employee }\end{array}$} & Industry & 33 & 15.6 \\
\hline & Health & 12 & 5.7 \\
\hline & Education & 29 & 13.7 \\
\hline & Public institutions & 12 & 5.7 \\
\hline & Other & 14 & 6.6 \\
\hline \multicolumn{2}{|l|}{ Unemployed } & 14 & 6.6 \\
\hline \multicolumn{2}{|l|}{ Student } & 88 & 41.5 \\
\hline \multicolumn{2}{|l|}{ Retired } & 10 & 4.7 \\
\hline \multicolumn{4}{|c|}{ Monthly net household income (in RSD) } \\
\hline \multicolumn{2}{|l|}{ Up to 50,000} & 71 & 33.5 \\
\hline \multicolumn{2}{|l|}{$50,001-100,000$} & 79 & 37.3 \\
\hline \multicolumn{2}{|l|}{$100,001-150,000$} & 27 & 12.7 \\
\hline \multicolumn{2}{|l|}{$150,001-200,000$} & 18 & 8.5 \\
\hline \multicolumn{2}{|l|}{ Exceeding 200,000 } & 17 & 8.0 \\
\hline \multicolumn{4}{|c|}{ Number of household members } \\
\hline \multicolumn{2}{|c|}{ Single-member household } & 17 & 8.0 \\
\hline Two-member housel & & 28 & 13.2 \\
\hline Three-member hous & old & 54 & 25.5 \\
\hline Four-member house & & 75 & 35.4 \\
\hline Five-member housel & & 23 & 10.8 \\
\hline Six and more memb & & 15 & 7.1 \\
\hline Overall & & 212 & 100 \\
\hline
\end{tabular}

Source: The data which the author obtained in his own field work 
In order to realize the aims of this study, we used a combination of an online interview and a personal interview. First, the questionnaire was prepared in electronic form and distributed to 350 previously selected e-mail addresses of inhabitants of the selected cities. The response rate of the on-line respondents was $43 \%$ and can be considered adequate and satisfactory. In the case of the remaining 63 respondents, the questionnaires were distributed in person, and the testing was conducted at various locations, starting from high schools, colleges to retail facilities. Approximately three weeks were needed for data collection, from May 8, 2014 until June 3, 2014.

\section{Questionnaire design}

The basic measuring instrument used in this study was a structured questionnaire which consisted of 21 questions organized into several groups. The first group of questions was meant to measure the level of knowledge and information that the respondents had about organic food, where the first question is a filter question which is used to single out a special group of informed respondents. This group also includes questions regarding awareness of the national organic label meant to determine the extent to which consumers recognize the labels on the products or whether they just purchase products randomly. At the same time, three labels were prepared: the first one is used for organic products which originate from the EU (Label 1), the second one is an imaginary label designed for the purpose of this research ${ }^{3}$ (Label 2), and the third one represents the national governmental label used in Serbia (Label 3) (Table 4.). The questionnaire continues with questions used to identify buying behavior. Another filter question was used here with the intention of separating organic food consumers from non-buyers of these products. The following block of questions attempts to determine which instruments of the marketing mix are most often selected by consumers. This includes their preferences for certain categories of products, price levels, distribution channels and means of communication. The final section of the questionnaire consists of socio-demographic questions.

Most of the questions were of the closed-type, presented in the form of two or multiple answer questions. In addition, scaling techniques were also used. ${ }^{4}$ Prior to formulating the final version of the questionnaire, we carried out a pilot study which included 50 representative respondents. The basic aim behind the pilot study, according to Saunders et al. (2009), was to improve its clarity, reliability and validity.

3 Design of the logo is taken from web research

4 The respondents who had not heard of the organic food were required to rate, on a scale of 1 to 5, their own knowledge of and the amount of information regarding organic food. 
Table 4. The recognition test for national organic label

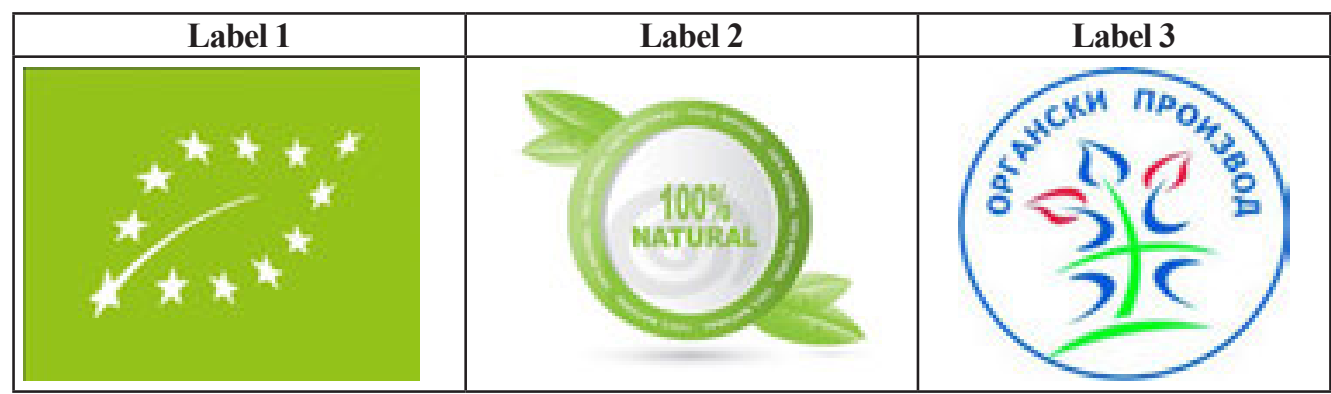

Source: Kalentić et al., 2014, Willer, Lernoud, 2014, 2015;

\section{Data analysis}

The collected data was processed using SPSS 21 (Statistical Program for Social Science) computer software. In processing the obtained data we used descriptive statistics and analytical statistic methods. Of the descriptive methods, relative values, central tendencies (means and modus) and standard deviations were noted. In order to study the statistical significance of the connection between categories of variables, the Chi-square test was used. The level of statistical significance was set at $\mathrm{p}<0,05$.

\section{Results and discussion}

\section{Information and knowledge about organic food}

The deciding influence on the demand for organic food is knowledge of the concept of organic food. More information on the organic food market, which leads to greater consumer knowledge of organic food, has a positive effect on consumers' attitudes towards these products. It was proven that attitudes are the main predictor of intentions for purchasing organic food products (de Magistris, Gracia, 2008; Yazdanpanah, Forouzani, 2015). The results of this study have shown that $4.2 \%$ of the respondents had not heard of organic food $^{5}$. This indicates that there are still individuals uninformed about the existence of food produced in the system of organic agriculture, but the percentage of these respondents was $8 \%$ smaller in comparison to previous studies carried out in Serbia (Vlahović et al., 2010; Vlahović et al., 2011).

The highest percentage of respondents $(43.3 \%)$ is considered to possess more than a sufficient level of information and knowledge about organic food (Table 5.). A subjective evaluation of the respondents is not in accordance with the results of the recognition test of the national organic label. The results of this test indicate a low level of familiarity with the label of organic food produced in Serbia, considering that almost $40 \%$ of the respondents did not manage to recognize the appropriate label (Graph 2.). The recognition problem and understanding of

5 The respondents who had not heard of organic food were excluded from further research and the final sample consists of only informed participants who are potential buyers of organic food. 
organic labels was identified in other studies (Padel, Foster, 2005; Roitner-Schobesberger et al., 2008; Sekovska, 2010; Vlahović et al., 2011; Mesías Díaz et al., 2012). The findings confirm that in the studied countries (Serbia, Thailand, Macedonia, Spain) more than half of the consumers could not recognize the national organic label or the EU label. Padel and Foster (2005) indicate that most of the respondents from the market of Great Britain are uncertain about the issues regarding inspection and certification and are clearly uninformed or confused about the labeling. The main source of confusion on the labeling of organic food is connected to the existence of a wide variety of competing products marked "safe food", "healthy food", "pesticide free", "chemical free" and "high quality food". The difficulties in distinguishing between them can be connected to the fact that most supermarkets on their shelves still do not make a proper and clear distinction between health food and organic food (Roitner-Schobesberger et al., 2008). This leads to consumers considering the terms organic food and health food to be more or less synonymous (Lockie, 2006; Gifford, Bernard, 2011).

Table 5. Descriptive indicators of the level of information and knowledge about organic food

\begin{tabular}{|c|c|c|c|c|c|}
\hline $\mathbf{N}$ & Min & Max & AS & SD & Modus \\
\hline 203 & 1 & 5 & 2.95 & 0.937 & 3 \\
\hline
\end{tabular}

Source: The data which the author obtained in his own field work

Graph 2. Recognition of the national organic label by the consumers

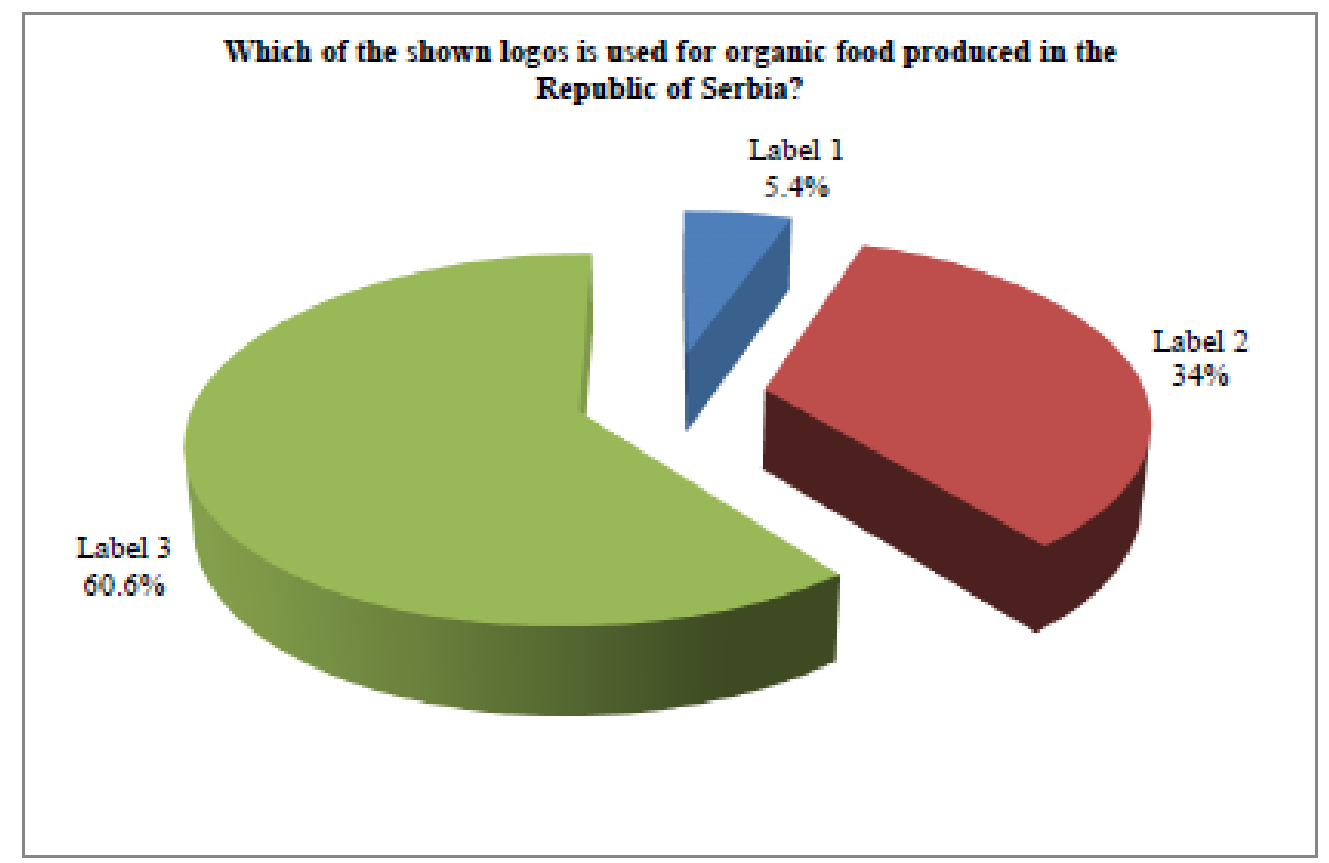

Source: The data which the author obtained in his own field work 
Even if the consumers are able to recognize the organic label, this does not mean that they have detailed information on the production process, certification and control. This was confirmed in this study, according to which only $10.8 \%$ of the respondents recognized the correct definition of organic food, defining it as food produced using techniques defined by the Law on Organic production (Table 6.).The results of the Chi-square test indicate a statistically significant connection between gender and the definition given of the concept of organic food $(\chi 2=13.743 ; \mathrm{df}=5 ; \mathrm{p}=0.017)$.Namely, of the respondents who correctly defined organic food most were female $(72.7 \%)$.

Table 6. Defining the concept of organic food

\begin{tabular}{|l|c|c|}
\hline \multicolumn{1}{|c|}{ Definition: Organic food } & $\begin{array}{c}\text { Absolute } \\
\text { frequency }\end{array}$ & $\begin{array}{c}\text { Relative } \\
\text { frequency (\%) }\end{array}$ \\
\hline Local food produced on family land using traditional methods & 21 & 10.3 \\
\hline $\begin{array}{l}\text { Food produced without the use of pesticides, chemical } \\
\text { additives and genetically modified organisms (GMO) }\end{array}$ & 66 & 32.5 \\
\hline Food produced without GMO & 4 & 2.0 \\
\hline $\begin{array}{l}\text { Food produced without the use of pesticides, artificial } \\
\text { fertilizers, GMO and chemical additives; }\end{array}$ & 70 & 34.5 \\
\hline $\begin{array}{l}\text { Food produced using techniques defined by the Law on } \\
\text { organic production }\end{array}$ & 22 & 10.8 \\
\hline $\begin{array}{l}\text { Food produced using natural methods without the use of } \\
\text { artificial fertilizers }\end{array}$ & 20 & 9.9 \\
\hline Overall & 203 & 100 \\
\hline
\end{tabular}

Source: The data which the author obtained in his own field work

\section{Buying behavior}

The development and improvement of a marketing strategy requires detailed information on the habits of consumers and their decision-making process regarding purchasing organic food. Of the overall number of informed respondents, $85.7 \%$ have indicated that they purchase organic food, while $14.4 \%$ had never purchased these products. ${ }^{6}$ The obtained results indicate that during the previous few years the demand for organic food has undergone an increase on the national market, considering that according to previous studies $46-48 \%$ of the participants could not be considered buyers of organic food (Vlahović et al., 2010, Vlahović et al., 2011). When it comes to purchasing frequency, it was determined that the greatest number of respondents $(45.3 \%)$ occasionally purchase OF, while only the smallest number are regular consumers of these products $(13.8 \%)$. This is in accordance with other studies which determined that the proportion of consumers purchasing organic food on a regular basis is low, while the greatest number of respondents only occasionally purchase organic products (Grunert, 1993; Wandel, Bugge, 1997; Vlahović et al., 2011, Mesías Díaz et al., 2012; Padilla Bravo et al., 2013). The results of the Chi-square test indicate a

6 The category of respondents who did not purchase these products was excluded from further analyses and the obtained sample consisted only of organic food consumers.

EP 2016 (63) 3 (871-889) 
statistically significant relation between socio-demographic characteristics and the frequency of purchasing organic food ${ }^{7}$ in three cases:

- $\quad$ Between the level of education and the purchasing frequency of organic food $(\chi 2=$ $10.537 ; \mathrm{df}=3 ; \mathrm{p}=0.015$ )

- $\quad$ Between occupation and purchasing frequency of organic food $(\chi 2=4.166 ; \mathrm{df}=1$; $\mathrm{p}=0.041)$

- $\quad$ Between the monthly net household income and purchasing frequency of organic food $(\chi 2=4.508, \mathrm{df}=1 ; \mathrm{p}=0.034)$

The abovementioned results reveal that respondents with a community college education or higher, respondents whose monthly net household income exceeds $100,000 \mathrm{RSD}^{8}$, as well as those who work in education, health, and public institutions often purchase organic food. This profile is in agreement with the results of other studies which support the fact that the purchasing of organic food is connected to a higher level of education and increased household income (Lockie et al., 2002; Radman, 2005; Aguirre González, 2009; Tung et al., 2012; Dimitri, Dettmann, 2012). Unlike in the case of socio-demographic variables, no statistically significant connection was established between the level of information and knowledge about organic food and the purchasing frequency of these products. This means that knowledge of the methods of organic production and awareness of the organic labels do not necessarily correspond purchase.

Fresh vegetables were the type of food that the respondents claim to purchase most often (55.7\%), followed by milk and dairy products (52.3\%) and honey (40.2\%) (Graph 3.).These results partly coincide with the results of previous studies, according to which the most frequently purchased categories of organic food include fruit and vegetables (Chinnici et al., 2002; O’Donovan, McCarthy, 2002; Radman, 2005; Roitner-Schobesberger et al., 2008; Vlahović et al., 2011). Based on our results, packaging does not represent an important factor when purchasing organic food, considering that $62.6 \%$ of consumers do not take into consideration packaging design when purchasing these types of products.

7 With the aim of proving the existence of a statistically significant relation between the aforementioned variables, we reduced the number of categorical variables, which confirmed in the basic hypothesis on the minimal theoretical frequency of any cell.

8 The dinar is the currency of Serbia. 
Graph 3. Most frequently bought organic products (in \%)

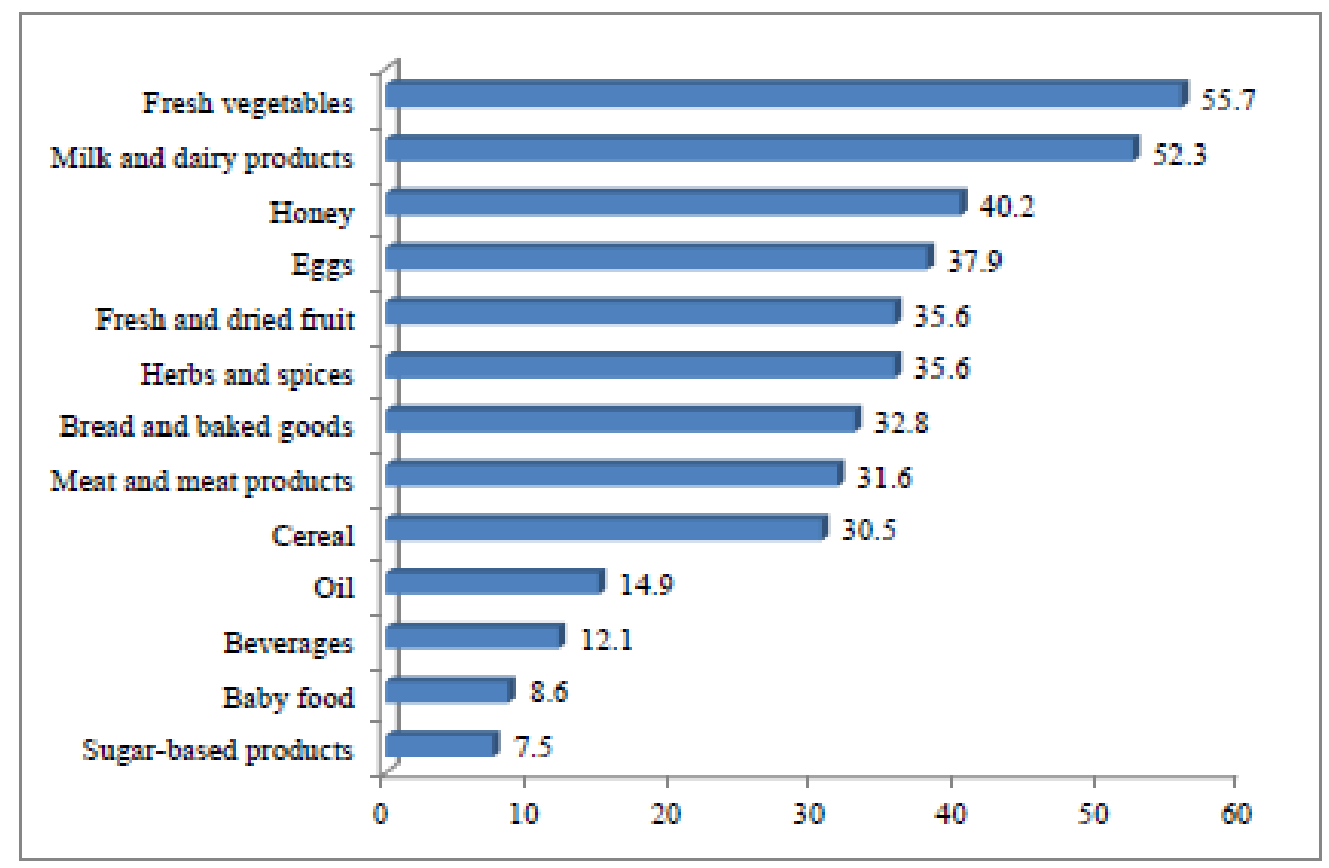

Source: The data which the author obtained in his own field work

Note: respondents were given the option of selecting more than one response

This study has shown that organic products is mostly purchased in supermarkets and hypermarkets (40.8\%) (Table 7.). The finding that supermarkets are the dominant place for purchasing organic products is supported by numerous studies (Lockie et al., 2002; Padel, Foster, 2005; Wier et al., 2008; Essoussi, Zahaf, 2008; Pellegrini, Farinello, 2009; MacKinnon, 2013). The results of this study suggest that specialized shops are important for a small percentage of consumers (12.1\%). According to previous studies carried out in Serbia, most of the respondents purchased these products in specialized shops, that is, "health food" stores (Vlahović et al., 2010; Vlahović et al., 2011). This would mean that both in Serbia and the West, the role of specialized shops in overall sales is decreasing, while the participation of supermarkets and hypermarkets is increasing. 
Table 7. Usual purchase place for organic products

\begin{tabular}{|l|l|c|c|}
\hline \multicolumn{2}{|c|}{ Categories } & $\begin{array}{c}\text { Absolute } \\
\text { frequency }\end{array}$ & $\begin{array}{c}\text { Relative frequency } \\
(\%)\end{array}$ \\
\hline \multirow{4}{*}{$\begin{array}{l}\text { Where do you usually purchase } \\
\text { organic food? }\end{array}$} & In the supermarket & 51 & 29.3 \\
\cline { 2 - 4 } & In a hypermarket & 20 & 11.5 \\
\cline { 2 - 4 } & In specialized shop & 21 & 12.1 \\
\cline { 2 - 4 } & At the green market & 27 & 15.5 \\
\cline { 2 - 4 } & $\begin{array}{l}\text { Directly from the } \\
\text { producer }\end{array}$ & 25 & 14.4 \\
\cline { 2 - 4 } & No rules & 30 & 17.2 \\
\hline
\end{tabular}

Source: The data which the author obtained in his own field work

The results of the Chi-square test indicate the influence of the type of food being purchased on the choice of purchasing place. The test results indicate that there is a statistically significant connection between:

- Purchasing fresh vegetables and the place of the purchase $(\chi 2=18.260 ; d f=6 ; p=$ $0.006)$

- Purchasing milk and dairy products and the place of the purchase $(\chi 2=13.771 ; \mathrm{df}=$ $6 ; \mathrm{p}=0.032)$

Namely, the greatest percentage of respondents buy fresh vegetables in supermarkets (33\%) and green markets $(22.7 \%)$, while they purchase milk and dairy products most often in supermarkets $(40.7 \%)$.

By analyzing the source of the information, it was determined that the greatest percentage of consumers obtained information on organic products on the internet (42.5\%) (Graph 4.). These results are in agreement with the results of studies of Greek consumers, most of whom stated that they obtained information on agricultural-food products on the internet (Baourakis et al., 2002). Contrary to that, Pellegrini and Farinello (2009) found that the internet is the least credible source of information on organic products, while consumers rely most on information contained in the product labels, followed by the information which they obtain at the location where they purchased the product, or the information they receive from their friends. 
Graph 4. Ranking the source of information on organic products according to importance

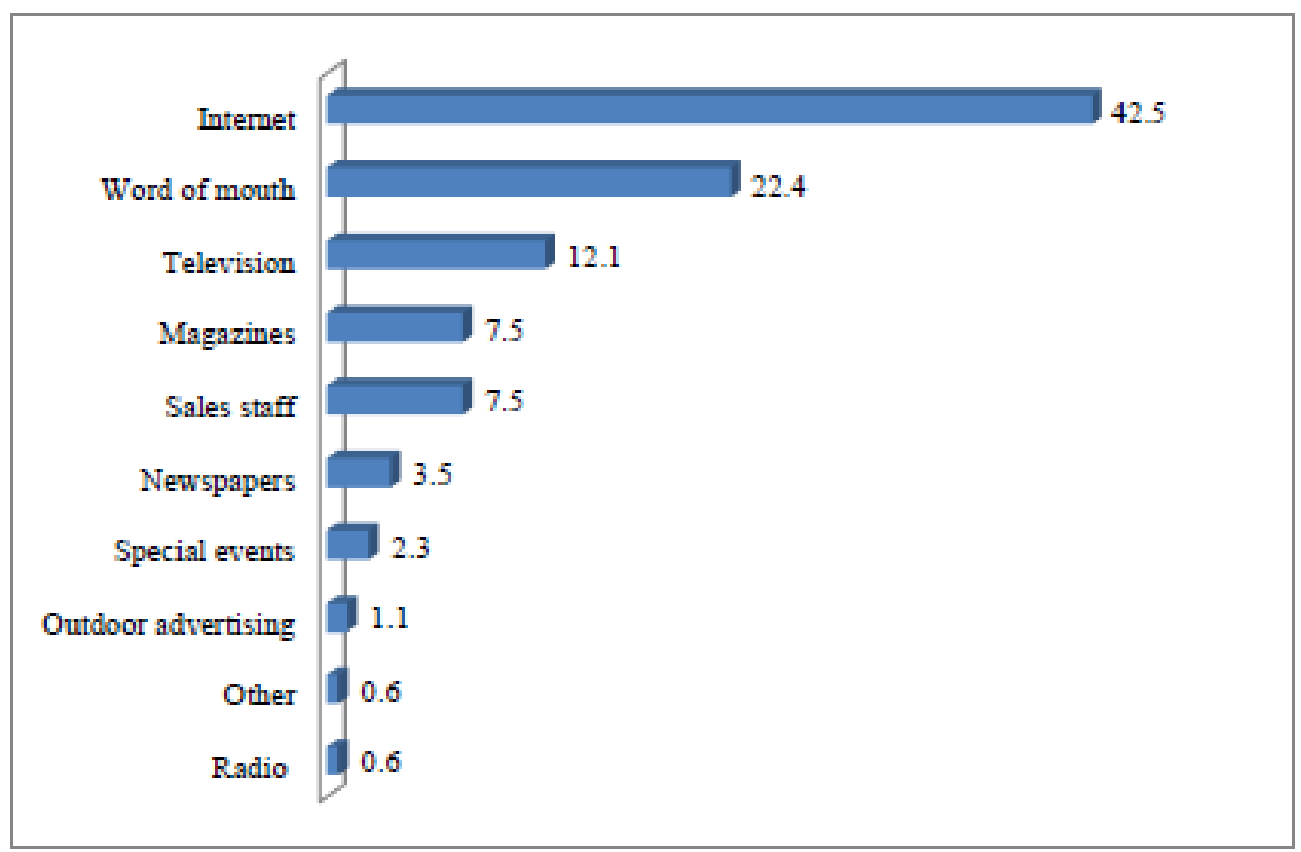

Source: The data which the author obtained in his own field work

\section{Willingness to pay for organic food}

Most of the consumers in Serbia (89.1\%) show a willingness to pay a higher price for organic food in comparison to the same types of conventionally produced food (Vehapi, 2015). Studies from various parts of the world found that most consumers are willing to pay premium prices for organic food (Wendel, Bugge, 1996; Canavari et al., 2002; O’Donovan, McCarthy, 2002; Aryal et al., 2009; Vlahović et al., 2011). A more detailed analysis indicated that $80.9 \%$ of consumers are willing to pay up to $30 \%$ higher price, while only $5.7 \%$ of consumers are willing to pay $100 \%$ higher price for organic products in comparison to the conventionally produced alternatives (Graph 5.).These results suggest that the intentions to purchase have a tendency to fluctuate, or decrease with the increase in the price of organic food. This would mean that the demand for organic food in Serbia show high price elasticity. Price elasticity of demand for different types of organic products was determined on the national markets of the United States of America and Germany (Jonas, Roosen, 2008; Lopez, Lopez, 2009). 
Graph 5. Simulation of price elasticity of demand for organic food

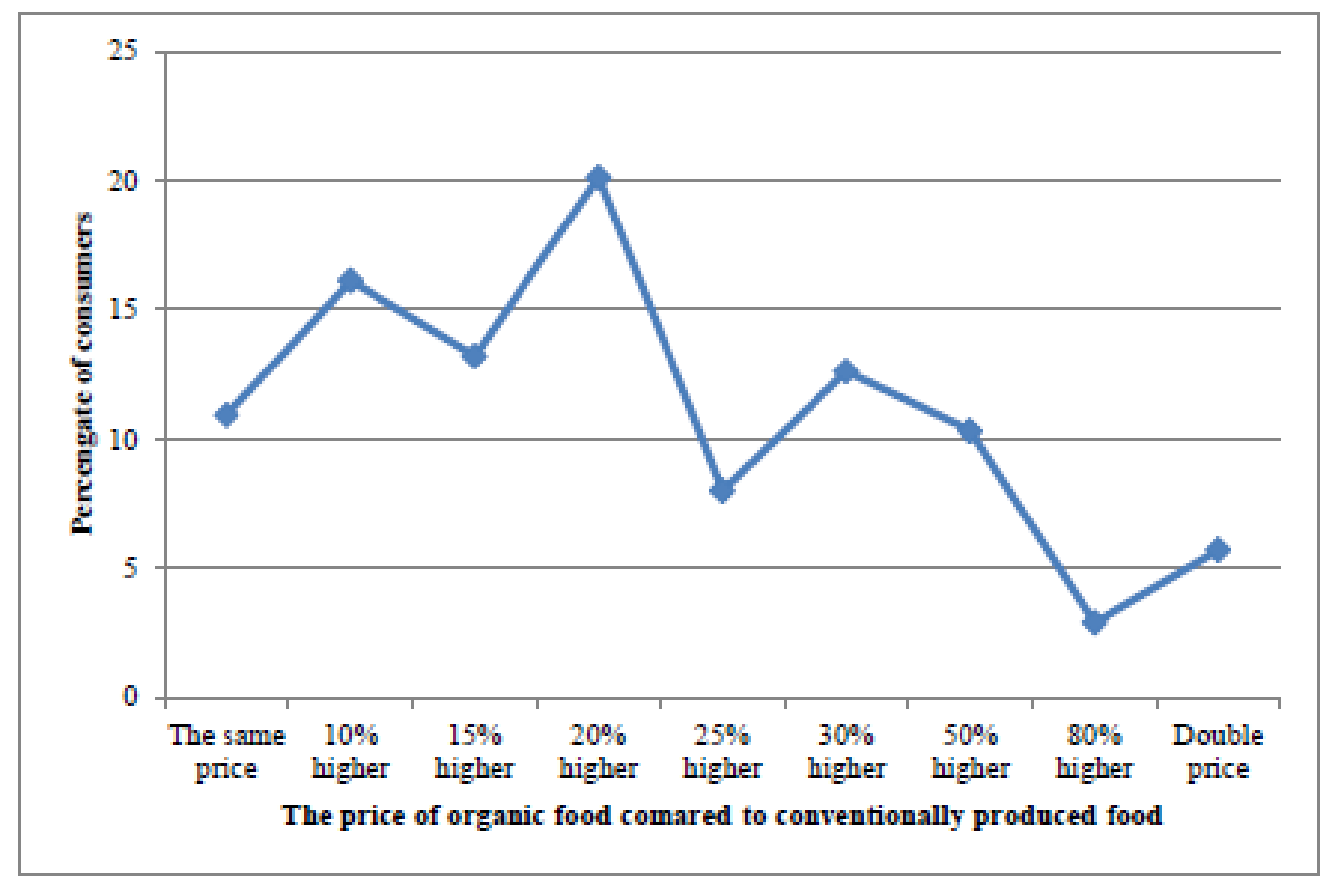

Source: The data which the author obtained in his own field work

\section{Conclusion}

Based on the quantitative study carried out in Serbia, it can be concluded that consumer awareness and knowledge regarding organic food are still at a low level. Even among more aware and interested individuals, only a small percentage of them purchase organic food regularly, which means that there is gap between preferences and their actual buying behavior. With the aim of increasing knowledge and awareness about organic food and their benefits, consumer education must become the primary task of organic producers. Considering that it is proven that socio-demographic variables are an important determinant of the purchasing frequency of organic food, the food industry in Serbia can increase its sales by targeting certain segments of consumers. Marketing should be focused on consumers with a greater income, higher education and consumers who work in education, health and the public sector.

The expressed consumer preferences towards certain product categories require the adjustment of the range of organic products available on the national market in terms of greater production of vegetables, milk and dairy products. The studied willingness of consumers to pay for organic food suggests that the strategy of lower prices could be an important means of attracting new buyers and converting occasional into regular consumers. In the long run, more subventions should be allocated to organic producers, which would increase the extent of the offer and consequently cause prices to go down. 
In combining instruments of the marketing mix, enough attention should be aimed at selecting the proper marketing channels, as well as the means and ways of marketing communication. Consumers on both the national and global market indicate a shift in their choice of purchase place from small-scale outlets to large-scale corporate retailers. Thus, the placement of organic products through large-scale food retailers, such as supermarkets and hypermarkets, represents an effective distribution strategy. In communication with the end user, producers and traders should focus on using the word of mouth, different advertising tools, and especially the internet, considering that these are the most important sources of information on organic food.

\section{References}

1. Aguirre González, J. A. (2009): Market trends and consumer profile at the organic farmers market in Costa Rica, British Food Journal, Vol. 111, No. 5, pp. 498-510.

2. Akbari, M., Asadi, A. (2008): A Comparative Study of Iranian Consumers'Versus Extension Experts' Attitudes towards Agricultural Organic Products (AOP), American Journal of Agricultural and Biological Sciences, Vol. 3, No. 3, pp. 551-558.

3. Aryal, K., Chaudhary, P., Pandit, S., Sharma, G. (2009): Consumers' Willingness to Pay for Organic Products: A Case From Kathmandu Valley, Journal of Agriculture and Environment, Vol.10, June 2009, pp. 15-26.

4. Baourakis, G., Kourgiantakis, M., Migdalas, A. (2002): The Impact of E-commerce on Agro-food Marketing. The Case of Agricultural Cooperatives, Firms and Consumers in Crete, British Food Journal, Vol. 104, No. 8, pp. 580 - 590.

5. Canavari, M., Bazzani, G.M., Spadoni, R., Regazzi, D. (2002): Food safety and organic fruit demand in Italy: a survey, British Food Journal, Vol. 104, No. 3/4/5, pp. 220 - 232.

6. Chinnici, G., D’Amico, M., Pecorino, B. (2002): A multivariate statistical analysis on the consumers of organic products, British Food Journal, Vol. 104, No. 3/4/5, pp. 187 199.

7. Crandall, P. G., Friedly, E. C., Patton, M., O’Bryan, C. A., Gurubaramurugeshan, A., Seideman, S., Ricke, C.S., Rainey, R. (2010): Estimating the Demand for Organic Foods by Consumers at Farmers' Markets in Northwest Arkansas, Journal of Agricultural \& Food Information, Vol. 11, No. 3, pp. 185-208.

8. De Magistris, T., Gracia,A. (2008): The decision to buy organic food products in Southern Italy, British Food Journal, Vol. 110, No. 9, pp. 929-947.

9. Dimitri, C., Dettmann, R.L. (2012): Organic food consumers: what do we really know about them, British Food Journal, Vol. 114, No. 8, pp. 1157 - 1183.

10. Doorn, J.V., Verhoef, P.C. (2015): Drivers of and Barriers to Organic Purchase Behavior, Journal of Retailing, Vol. 91, No. 3, pp. 436-450.

11. Essoussi, L.H., Zahaf, M. (2008): Profiling Organic Food Consumers: Motivations, Trust Orientations and Purchasing Behavior, Journal of International Business and Economics, Vol. 8, No. 2, pp. 25-39. 
12. Fotopoulos, C., Krystallis, A. (2002): Purchasing motives and profile of the Greek organic consumer: a countrywide survey, British Food Journal, Vol. 104, No. 9, pp. 730765.

13. Gifford, K., Bernard, J.C. (2011): The effect of information on consumers ' willingness to pay for natural and organic chicken, International Journal of Consumer Studies, Vol. 35, No. 3, pp. 282-289.

14. Govindasamy, R., Italia, J. (1999): Predicting Willingness-to-Pay a Premium for Organically Grown Fresh Produce, Journal of Food Distribution Research, Vol. 30, No. 2, pp. 44-53.

15. Grubor, A., Djokić, N. (2016): Organic food consumer profile in the Republic of Serbia, British Food Journal, Vol. 118, No. 1, pp. 164-182.

16. Grunert, S.C. (1993): Green consumerism in Denmark: Some evidence from the ØKO foods-project, International Journal of Marketing, Vol. 32, No. 3, pp. 140-151.

17. Hill, H., Lynchehaun, F. (2002): Organic milk: attitudes and consumption patterns, British Food Journal, Vol. 104, No. 7, pp. 526-542.

18. Janssen, M., Hamm, U. (2011): Consumer perception of different organic certification schemes in five European countries, Organic Agriculture, Vol. 1, No. 1, pp. 31-43.

19. Jonas, A., Roosen, J. (2008): Demand for milk labels in Germany: organic milk, conventional brands, and retail labels, Agribusiness, Vol. 24, No. 2, pp. 192-206.

20. Kalentić, M., Stefanović, E., Simić, I., Maerz, U. (2014): Organic Agriculture in Serbia: at a glance 2014, GIZ-Deutsche Gesellschaft für Internationale Zusammenarbeit GmbH, National Association Serbia Organica, Beograd, Serbia.

21. Krystallis, A., Fotopoulos, C., Zotos, Y. (2006): Organic Consumers' Profile and Their Willingness to Pay (WTP) for Selected Organic Food Products in Greece, Journal of International Consumer Marketing, Vol. 19, No. 1, pp. 81-106.

22. Lockie, S., Lyons, K., Lawrence, G., Mummery, K. (2002): Eating 'Green’: Motivations behind organic food consumption in Australia, Sociologia Ruralis, Vol. 42, No. 1, pp. 23-40.

23. Lockie, S. (2006): Capturing the Sustainability Agenda: Organic Foods and Media Discourses on Food Scares, Environment, Genetic Engineering, and Health, Agriculture and Human Values, Vol. 23, No. 3, pp. 313-323.

24. Lopez, E., Lopez, R.A. (2009): Demand for differentiated milk products: implications for price competition, Agribusiness, Vol. 25, No. 4, pp. 453-465.

25. MacKinnon, S. (2013). The BC organic market: growth, trends and opportunities, 2013., (available at: https://ota.com/sites/default/files/indexed files/COTA NationalOrganicMarketSummary.pdf)

26. Mesias Díaz, F.J., Martinez-Carrasco Pleite, F., Miguel Martinez Paz, J., Gaspar García, P. (2012): Consumer knowledge, consumption, and willingness to pay for organic tomatoes, British Food Journal, Vol. 114, No. 3, pp. 318-334. 
27. O'Donovan, P., McCarthy, M. (2002): Irish Consumer Preference for Organic Meat, British Food Journal, Vol. 104, No. 3/4/5, pp. 353 - 370.

28. Padel, S., Foster, C. (2005): Exploring the gap between attitudes and behaviour: Understanding why consumers buy or do not buy organic food, British Food Journal, Vol. 107, No. 8, pp. 606-625.

29. Padilla Bravo, C., Cordts, A., Schulze, B., Spiller, A. (2013): Assessing determinants of organic food consumption using data from the German National Nutrition Survey II, Food Quality and Preference, Vol. 28, No. 1, pp. 60-70.

30. Pellegrini, G., Farinello, F. (2009): Organic consumers and new lifestyles: An Italian country survey on consumption patterns, British Food Journal, Vol. 111, No. 9, pp. 948974.

31. Radman, M. (2005): Consumer consumption and perception of organic products in Croatia, British Food Journal, Vol. 107, No. 4, pp. 263-273.

32. Roitner-Schobesberger, B., Darnhofer, I., Somsook, S., Vogl, C.R. (2008): Consumer perceptions of organic foods in Bangkok, Thailand, Food Policy, Vol. 33, No. 2, pp. 112121.

33. Saunders, M., Thornhill, A., Lewis, P. (2009): Research Methods for Business Students, Pearson Education, Harlow, England.

34. Sekovska, B. (2010): Organic food supply chain - the case in Macedonia, Economics of Agriculture, Vol. 57, No. 2, pp. 171-178.

35. Tsakiridou, E., Zotos, Y., Mattas, K. (2006): Employing a Dichotomous Choice Model to Assess Willingness to Pay (WTP) for Organically Produced Products, Journal of Food Products Marketing, Vol. 12, No. 3, pp. 59-69.

36. Tung, S.J., Shih, C.C., Wei, S., Chen, Y.H. (2012): Attitudinal inconsistency toward organic food in relation to purchasing intention and behavior: An illustration of Taiwan consumers, British Food Journal, Vol. 114, No. 7, pp. 997-1015.

37. Vehapi, S. (2015): A study of the consumer motives which influence the purchase of organic food in Serbia, Economic Themes, Vol. 53, No. 1, pp. 102-118.

38. Vlahović, B., Puškarić, A., Jeločnik, M. (2011): Consumer Attitude to Organic Food Consumption in Serbia, Petroleum Gas University of Ploiesti Bulletin, Vol. 18, No. 1, pp. 45-52, National Institute of Economic Research, Bucharest, Romania, (available at: http://www.upg-bulletin-se.ro/archive/2011-1/6.\%20Vlahovic Puskaric Jelocnik.pdf).

39. Vlahović, B., Tomić, D., Popović, V. (2010): Stanje i perspektive potrošnje proizvoda organske poljoprivrede,. Conference on organic agriculture „Selenča”, Selenča, Serbia, (available at: http://organiccentar.rs/sites/default/files/radovi sa foruma/ STANJE\%20I\%20PERSPEKTIVE\%20POTRO\%C5\%A0NJE\%20PROIZVODA\%20 ORGANSKE\%20POLJOPRIVREDE.pdf)

40. Wandel, M., Bugge, A. (1997): Environmental concern in consumer evaluation of food quality, Food Quality and Preference, Vol. 8, No. 1, pp. 19-26.

41. Wier, M., Jensen, K.O.D., Andersen, L.M., Millock, K. (2008): The character of demand 
in mature organic food markets: Great Britain and Denmark compared, Food Policy, Vol. 33, No. 5, pp. 406-421.

42. Willer, H., Lernoud, J. (2014): The World of Organic Agriculture: Statistics and Emerging Trends 2014, Research Institute of Organic Agriculture (FiBL), Frick, and International Federation of Organic Agriculture Movements (IFOAM), Bonn, Germany, (available at: http://orgprints.org/25172/1/willer-lernoud-2014-world-of-organic.pdf)

43. Willer, H., Lernoud, J. (2015): The World of Organic Agriculture. Statistics and Emerging Trends 2015, Research Institute of Organic Agriculture (FiBL), Frick, and International Federation of Organic Agriculture Movements (IFOAM), Bonn, Germany, (available at: https://shop.fibl.org/fileadmin/documents/shop/1663-organic-world-2015.pdf)

44. Willer, H., Lernoud, J. (2016): The World of Organic Agriculture. Statistics and Emerging Trends 2016, Research Institute of Organic Agriculture (FiBL), Frick, and International Federation of Organic Agriculture Movements (IFOAM), Bonn, Germany, (available at: https://shop.fibl.org/fileadmin/documents/shop/1698-organic-world-2016.pdf)

45. Yazdanpanah, M., Forouzani, M. (2015): Application of the Theory of Planned Behaviour to predict Iranian students' intention to purchase organic food, Journal of Cleaner Production, Vol. 107, 16 November 2015, pp. 342-352. 


\title{
PONAŠANJE POTROŠAČA U POGLEDU POTROŠNJE ORGANSKE HRANE: DOKAZI IZ REPUBLIKE SRBIJE
}

\author{
Semir Vehapi ${ }^{9}$ Edin Dolićanin ${ }^{10}$
}

\begin{abstract}
Rezime
U razvijenim zemljama tražnja za organskom hranom ostvaruje snažan rast tokom poslednje decenije. Nasuprot tome, tržište organske hrane u Srbiji je u početnoj fazi razvoja i može se smatrati tržištem u nastajanju. Dubljim razumevanjem ponašanja potrošača na tržištu Srbije moguće je kroz adekvatan marketing pristup obezbediti veću per capita potrošnju organske hrane i brži razvoj nacionalnog tržišta. U ovom radu predstavljeni su najvažniji rezultati do kojih se došlo na osnovu kvantitativnog istraživanja stanovnika Srbije u ulozi kupaca i potencijalnih kupaca organske hrane. Istražen je i predočen nivo znanja ispitanika $u$ vezi organskih prehrambenih proizvoda, i otkriven je socio-demografski profil potrošača kao važna determinanta potrošnje datih proizvoda. Pored toga, analizirano je ponašanje potrošača pri kupovini organske hrane sa stanovišta osnovnih instrumenata marketing miksa: proizvoda, cene, marketing komuniciranja i kanala marketinga. Dobijeni rezultati su objašnjeni u odnosu na teorijsko znanje stečeno iz ranijih istraživanja sprovedenih na različitim nacionalnim tržištima. Na osnovu toga obezbeđena je čvrsta osnova za razvoj efikasnih marketing strategija.
\end{abstract}

Ključne reči: organska hrana, tržište, potrošači, ponašanje, Srbija

9 Dr Semir Vehapi, Asistent, Državni univerzitet u Novom Pazaru, Departman za Ekonomske nauke (Kabinet br. 23), Ulica Vuka Karadžića bb, 36300 Novi Pazar, Republika Srbija, Telefon: +381638618 381, E-mail: svehapi@np.ac.rs

10 Docent, dr Edin Dolićanin, Državni univerzitet u Novom Pazaru, Departman za Tehničke nauke Ulica Vuka Karadžića bb, 36300 Novi Pazar, Republika Srbija, Telefon: +381 6366 55 02, E-mail: edin.dolicanin@yahoo.com

EP 2016 (63) 3 (871-889) 